\title{
Clonal selection of Argan trees (Argania spinosa L. Skeels) in the Admin forest, Agadir, Southwestern Morocco
}

\author{
Ait Hammou, R. ${ }^{1,2 \star} \bullet$ Harrouni, M.C. ${ }^{3} \bullet$ Cherifi, K. $^{4} \bullet$ Hallouti A. ${ }^{5} \bullet$ Daoud, S. ${ }^{1}$
}

'Laboratoire de Biotechnologies végétales, Faculté des Sciences, Université lbn Zohr, Agadir

${ }^{2}$ Direction des Domaines Agricoles (Les Arômes du Maroc), Agadir.

${ }^{3}$ Département Paysage et Environnement, I.A.V. Hassan II, Agadir.

${ }^{4}$ Laboratoire de Biotechnologies et Valorisation des Ressources Naturelles.

${ }^{5}$ Laboratoire de Biotechnologies microbiennes et protection des végétaux.

*Corresponding author. E-mail: rachidaithammou87@gmail.com.

Accepted $9^{\text {th }}$ April, 2018.

\begin{abstract}
The Argan (Argania spinosa L. Skeels) is a multipurpose tree endemic to Morocco. As such it plays an important economic role. However, these naturally occurring trees present a huge variability in terms of biomass production and fruit yield. The actual tendency in Morocco is to promote Argan tree planting for oil production. Nevertheless, for this purpose it would be more rewarding to propagate trees with desirable characteristics such as fruit and oil yield, nut crushing easiness and low rate of yield alternation from one year to another. The objective of the present work is to select performing specimens among a population of old trees (over 50 years old) and young ones (7 years) located in a 100 ha land in Admin forest (Agadir), Morocco. The old population pool is composed of 1000 trees and the young one comprises 9000 trees. Selection was based on several criteria but yield and alternation rate were the most important. Climate parameters have been also taken into consideration. Correlation between rainfall, strong winds and Chergui (a dry and hot wind coming from south and southeast) showed that climatic conditions affect Argan productivity. Over the 3 years that this study has lasted, and using ANOVA (analysis of variance) and PCA (principal component analysis) analyses, it was possible to distinguish 5 old and 5 young trees for their superiority in terms of almond and oil yield. These performing old and young trees are labeled in the field and geographically localized using a GPS for latitude and longitude coordinates. Further work is required to use vegetative propagation to ensure that the desirable characters set herein are maintained in daughter plants.
\end{abstract}

Keywords: Argan tree, oil yield, alternation rate, clonal selection, climate parameters.

\section{INTRODUCTION}

The Argan tree (Argania spinosa L. Skeels) is a naturally occurring multipurpose species endemic to Morocco. It plays a very important socioeconomic and ecological role. This tree formation covers over 800,000 ha and its area was recognized as a biosphere reserve by UNESCO in 1998 (Morton et al., 1987). The Argan tree is characterized by a great genetic diversity (El Mousadik, 1997; Msanda et al., 2005; Ait Aabd et al., 2010; Mouhaddab et al., 2017) maintained in nature by a largely allogamic reproduction mode (Msanda, 1993). However, desertification, overgrazing and lack of favorable conditions for natural regeneration have caused 
an alarming reduction in the area of Argan tree forests (Defaa et al., 2013). The Argan deforestation results from the combination of the absence of regeneration and the loss of trees. The lack or even the absence of regeneration of the Argan forest has long been recognized.

The estimation of Argan tree yields varies greatly depending on the regions and on the tree ecotypes. Msanda (1993) gives an estimation of $500 \mathrm{~kg} / \mathrm{ha}$, without specifying the number of trees per hectare. The productivity of Argan trees is also favored by rainfalls of at least $100 \mathrm{~mm}$ in autumn and maximum mild temperatures (Bani-Aameur et al., 2010). The oil content of almonds is also very variable according to genotypes. The percentage of oil varies between 2.7 and $3.1 \%$. The oil content of almonds ranges from 39.2 to $44.1 \%$. This shows that there is a potential for genetic improvement of this species in the framework of a domestication program as a fruit tree for oil production (Bani-Aameur, 2001).

Plantations established with seeds lead to a considerable heterogeneity of progeny. Genetic characterization using molecular markers (inter-simple sequence repeat (ISSR) markers) showed strong genetic diversity within and between provenances. Selection based on oil yield can be considered very important because of its great heritability (Aït Aabd, 2013).

Propagation by seed showed considerable heterogeneity in growth rate, plant architecture, flowering and production of useful biomass (El Mousadik, 1997). Theoretically, vegetative propagation remains a better alternative to optimize a homogenous production of Argan plants to overcome diversity of seedlings obtained from seeds. However, in spite of efforts made for Argan tree propagation, so far, no Argan tree ecotype has been identified on which an intensive multiplication program can be based.

In the last decades, several studies have been carried out to investigate genetic variability of the Argan tree. These studies have shown that Argan has a great agromorphological and genetic diversity (Ferradous, 1995; El Mousadik, 1997; Ferradous et al., 2010; Aït Aabd et al., 2010; Mouhaddab et al., 2017). Furthermore, those studies were only based on qualitative characteristics (Nouaïm et al., 2007) or they were limited in time (Fallah, 2004; Azenfar et al., 2007; Bellefontaine, 2010). However, selection criteria, which are very important to domesticate this species as an oleaginous fruit tree, remain poorly studied on a single tree basis (fruit and biomass production, oil yield and the rate of yield alternation between years). These parameters represent some of the most important factors. Moreover, propagation by seeds, cuttings and grafting remains relatively little studied.

The focus of the present work is on Argan tree clonal selection among a large population in the forest of Admin, located 20 kilometers east of Agadir city, Morocco. Its aim is to identify clone heads in a very diverse Argan tree population consisting of more than 9000 seedlings propagated from seeds originating from different ecological zones (Tiznit, Essaouira and Taroudant) and 1000 old preexisting plants.

\section{MATERIALS AND METHODS}

\section{Site location}

The data used in this study are derived from a forest plot covering an area of 100 ha in the Admin forest (Figure 1) (coordinates $9^{\circ} 36^{\prime} 22^{\prime \prime} \mathrm{W}$ and $33^{\circ} 55^{\prime} 39^{\prime \prime} \mathrm{N}$ ) and the altitude above sea level is $63 \mathrm{~m}$ (El Mrabet et al., 2014).

\section{Climate data}

In general, the climate in the Admin forest can be described as Mediterranean and arid with an average annual precipitation of $230 \mathrm{~mm}$. Between January 2013 and December 2016, the annual rainfall was 292.5, $509.2,114$ and $159 \mathrm{~mm}$, respectively (Table 1 ).

The years 2013, 2014, 2015 and 2016 showed respectively $11,20,15$ and 16 days of strong winds that had a speed over $16 \mathrm{~m} / \mathrm{s}$. The Chergui (Sirocco) in Morocco is a hot and dry wind coming from the east or the southeast. The accumulated number of days of Chergui occurrence between 2013 and 2016 was 54, 37, 68 and 49 respectively. The average yearly maximum temperature for the 4 years was $26.12^{\circ} \mathrm{C}$ and the average yearly minimum was $13.57^{\circ} \mathrm{C}$.

\section{Physicochemical analyses of soil and water}

In the study site, three soil profiles were dug in different location so that we have a good representation. The profiles showed 3 horizons (A, B and C). Soil samples were taken from each horizon for laboratory analyses which included particle size, $\mathrm{pH}$, electrical conductivity (EC), organic matter (OM) content, chemical composition (available phosphorus, total nitrogen, Nitrate, Potassium, Sodium, Calcium, Magnesium, iron, copper, zinc, and Manganese). Analyses were carried out according to the classical methods as described by Page et al. (1982).

\section{Biomass and yield characterization}

The age of the seedlings was 7 years in 2014 whereas the age of old trees is not known (surely over 50 years after the last coppicing). The Argan plantations (young and old) received two irrigations per year of 100 liters of well water $(\mathrm{pH}=7.70$ and $\mathrm{EC}$ (electrical conductivity) = $1.24 \mathrm{dS} / \mathrm{m})$.

All trees of each category were labeled as YT1-YT9000 


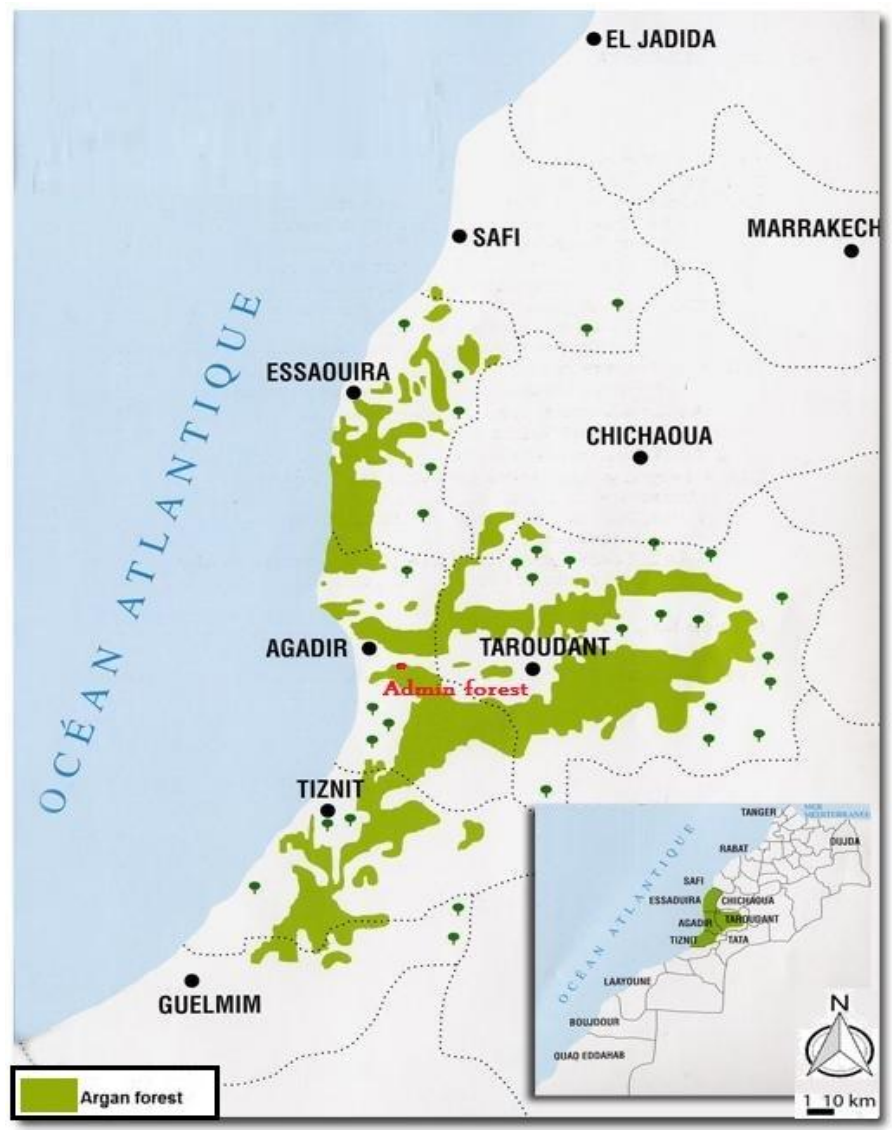

Figure 1. Site location (Msanda et al., 2005).

for the young population and as OT1-OT1000 for the old population. Out of these two populations, one hundred trees from each category (young and old) were preselected for their high level of productivity. They were labeled as YTx for the young trees and OTx for the old ones. These preselected trees were characterized by measuring some quantitative and qualitative parameters detailed below.

\section{Quantitative parameters}

The quantitative parameters studied between January 2014 and September 2016 were: annual fruit production, fruit production per $\mathrm{m}^{3}$ of canopy, fresh weight, unit number in $100 \mathrm{~g}$ of fruits, almond yield, oil yield, trunk stemming, trunk circumference (when a tree presents several stems, circumference is calculated as the total of stem circumferences), crown volume, and alternation rate.

The crown volume was calculated by the computation of the volume of an ellipsoid (crown volume $=4 / 3 \pi$ a.b.c) because this model is closer to the tree volume (Zunzunegui et al., 2010).
The yield of almonds was calculated by hand crushing of $10 \mathrm{~kg}$ for old trees and $1 \mathrm{~kg}$ for young ones with three replicates. Oil yield was measured after mechanical extraction of the almonds obtained from seed crushing. The alternation rates were determined by calculating the average differences in yield between two years $(2014 / 2015,2015 / 2016$ and $2014 / 2016)$ by the following formula:

$\operatorname{AR}(\%)=[\mathrm{N}-(\mathrm{N}-1)] /(\mathrm{N}-1) * 100$

$\mathrm{N}=$ harvest of the year

$\mathrm{N}-1=$ harvest of the previous year

\section{Qualitative parameters}

In parallel, some qualitative parameters cited in other works were studied such as fruit form, presence of spines and ease of crushing. Fruit shape was distinguished as described by Ferradous (1995). The presence of spines was determined by counting the number of spines of ten $10-\mathrm{cm}$-cuttings in the middle of the tree. The ease of crushing was estimated by calculating the ratio of almond to seed weight (Nouaïm et al., 2002).

\section{Selection of productive trees}

In May 2014, the most productive trees (young and old) were identified and labeled based on seed harvest. The best 100 trees of each category (young and old) were chosen for further investigation.

In order to reduce the large number of trees, after yield analysis of 3 successive years, trees that maintained an overall important yield (above the average) were considered as best specimens. This allowed selecting 31 young trees and 48 old trees.

\section{Statistical analysis}

The results were analyzed by one-way and multiple factors ANOVA. The projection of individuals by Principal Component Analysis (PCA) and correlation tests using phenotypic characterization data enabled the identification of clone heads. The homogeneous groups are determined by the test of Newman and Keuls with $\alpha=$ $5 \%$. These statistical processes are carried out using Statistica V6 software.

\section{RESULTS AND DISCUSSION}

\section{Soil quality}

Analysis of sampled soil showed that it is generally 
Table 1. Climate data of the study area (Meteorological station of Al Massira Airport, 2017).

\begin{tabular}{lccccc}
\hline Year & Rainfall (mm) & Strong winds (days) & Chergui winds (days) & Average $\max \mathbf{T}^{\circ} \mathbf{C}$ & Average $\min \mathbf{~}{ }^{\circ} \mathbf{C}$ \\
\hline 2013 & 292.5 & 11 & 54 & 26.18 & 13.01 \\
2014 & 509.2 & 20 & 37 & 25.9 & 13.8 \\
2015 & 114 & 15 & 68 & 26.28 & 13.45 \\
2016 & 159 & 16 & 49 & 26.13 & 14.04 \\
Average & 268.67 & 15.5 & 52 & 26.12 & 13.57 \\
\hline
\end{tabular}

Table 2. Soil particle size in the study site.

\begin{tabular}{llccccc}
\hline Profiles & Horizon & Clay (\%) & Fine silt (\%) & Coarse silt (\%) & Fine sand (\%) & Coarse sand (\%) \\
\hline \multirow{3}{*}{1} & A $(0-36 \mathrm{~cm})$ & 9.30 & 17.45 & 20.32 & 44.23 & 8.68 \\
& B (36-55 cm) & 9.85 & 16.50 & 20.28 & 42.51 & 10.84 \\
& C (>55 cm) & 12.60 & 15.50 & 18.58 & 37.88 & 15.44 \\
& & & & & & \\
2 & A $(0-40 \mathrm{~cm})$ & 8.30 & 12.90 & 15.55 & 50.22 & 13.03 \\
& B (40-68 cm) & 10.45 & 12.00 & 10.38 & 53.59 & 13.57 \\
& C (>68 cm) & 10.20 & 20.75 & 5.49 & 29.59 & 23.77 \\
& & & & & & \\
3 & A (0-55 cm) & 9.05 & 16.80 & 16.33 & 49.59 & 8.23 \\
& B (55-71 cm) & 10.70 & 15.15 & 22.96 & 50.04 & 11.15 \\
& C (>71 cm)) & 12.20 & 22.25 & 12.94 & 20.99 & 31.62 \\
\hline
\end{tabular}

composed of 3 horizons ( $A, B$ and $C$ ) but with different depths ranging from 36 to $55 \mathrm{~cm}$ for horizon A, 19 to 28 $\mathrm{cm}$ for horizon B and over $55 \mathrm{~cm}$ for horizon C (Table 2).

Laboratory analyses showed that the texture is sandysilty loam, sand representing over $50 \%$. The clay fraction is below $13 \%$ in all horizons of all profiles (Table 2). The $\mathrm{pH}$ is alkaline with values ranging from 8.25 to 8.73 (Table 3 ). EC is low (0.056 to 0.252) indicating that the soil is not saline. Organic matter is generally low (1.2 and below) in all profiles and horizons. Lime is relatively low in the upper horizons and high in $\mathrm{C}$ horizon indicating the calcareous nature of the subsoil. Chemical elements are in accordance with the low organic matter content.

Our results showed that the soil is generally alkaline with a $\mathrm{pH}$ above 8 and variable chemical compositions according to profile and horizon (Table 2).

\section{Biomass and yield characterization}

Table 4 shows biomass parameters in terms of crown volume, number of stems per tree and total trunk circumference.

The crown volume was obviously higher in the old population but variability is high (Table 4). However, the number of stems per tree was comparable between the old and the young populations. Trunk circumference per stem shows that on average, old trees have trunks 3.5 times bigger than young ones (Table 4) which is understandable.
Table 5 shows the fruit yields of 100 young and 100 old trees for 3 years. Figures show an important variation from one year to another among the same population. The table also shows the effect of the season and the age on fruit yield. For the old trees, yield variation was $55 \%$ in 2015 and $-35 \%$ in 2016 compared to 2014 . For the young trees, yield variation ranged from $-25 \%$ to $+70 \%$, comparing 2015 and 2016 with 2014 (Table 5). During the three years of study, maximum fruit yields per tree were $118 \mathrm{~kg}$ from the old population and $13 \mathrm{~kg}$ from the young one. Some trees did not give any yield at all as the case of old trees in 2015 and young trees in the 3 years. This can be explained by the alternation phenomenon in the Argan tree as it happens in other species like the olive tree. Some trees produce fruit every year, others every other year and others over a period of more than three years (Ferradous, 1995; Bani-Aameur et al., 2010).

As presented earlier, fruit types in terms of overall shape were distinguished. Table 6 shows the percentage of fruit type for each tree category (young or old).

\section{Effect of fruit form on some selection parameters}

The analysis of variance was applied to the database of old trees to determine the relationship between fruit form and some selection criteria cited (Table 7). The ANOVA table shows that fruit form has a significant effect on oil yield while there is no effect on other parameters. 
Table 3. Chemical characterization of the soil of the study site.

\begin{tabular}{|c|c|c|c|c|c|c|c|c|c|c|c|c|c|c|c|}
\hline \multirow{2}{*}{ Profiles } & \multirow{2}{*}{ Horizons } & \multirow{2}{*}{$\mathrm{pH}$} & \multirow{2}{*}{$\mathrm{EC}(\mathrm{dS} / \mathrm{m})$} & OM & $\mathrm{CaCO}_{3}$ & $\mathrm{NO}_{3}$ & $\mathrm{P}_{2} \mathrm{O}_{5}$ & $\mathrm{~K}^{+}$ & $\mathrm{Na}^{+}$ & $\mathrm{Ca}^{2+}$ & $\mathrm{Mg}^{2+}$ & $\mathrm{Fe}$ & $\mathrm{Cu}$ & $\mathrm{Zn}$ & $\mathbf{M n}$ \\
\hline & & & & \multicolumn{2}{|c|}{ (\%) } & \multicolumn{6}{|c|}{$(\% 0)$} & \multicolumn{4}{|c|}{ (ppm) } \\
\hline \multirow{3}{*}{1} & $A$ & 8.40 & 0.073 & 1.22 & 6.75 & 1.74 & 0.025 & 0.482 & 0.154 & 0.965 & 0.326 & 14.6 & 4.5 & 0.8 & 111.5 \\
\hline & B & 8.36 & 0.122 & 1.06 & 11.70 & 1.16 & 0.077 & 0.294 & 0.123 & 1.062 & 0.508 & 8 & 4 & 0.8 & 45.25 \\
\hline & $C$ & 8.63 & 0.252 & 0.60 & 22.95 & 1.16 & 0.012 & 0.187 & 0.061 & 7.825 & 0.151 & 15.3 & 3 & 0.6 & 63 \\
\hline \multirow{3}{*}{2} & $A$ & 8.73 & 0.078 & 0.82 & 9.54 & 6.39 & 0.027 & 0.455 & 0.077 & 0.868 & 0.133 & 5.3 & 4 & 0.7 & 50.25 \\
\hline & B & 8.71 & 0.056 & 0.43 & 25.74 & 1.16 & 0.019 & 0.374 & 0.138 & 0.965 & 0.405 & 4 & 1.5 & 0.7 & 28.5 \\
\hline & C & 8.31 & 0.198 & 0.27 & 65.04 & 0.58 & 0.064 & 0.214 & 0.092 & 10.234 & 0.211 & 1.3 & 2 & 0.4 & 62 \\
\hline \multirow{3}{*}{3} & $A$ & 8.25 & 0.083 & 1.75 & 6.88 & 7.55 & 0.022 & 12.535 & 3.195 & 15.68 & 0.534 & 0.5 & 0.5 & 0.5 & 1.9 \\
\hline & B & 8.54 & 0.112 & 0.80 & 45.45 & 3.13 & 0.021 & 3.856 & 2.39 & 13.16 & 0.358 & 0.6 & 0.8 & 0.5 & 0.9 \\
\hline & C & 8.46 & 0.144 & 0.22 & 68.18 & 1.74 & 0.057 & 2.169 & 2.19 & 11.48 & 0.273 & 0.5 & 0.6 & 0.5 & 0.5 \\
\hline
\end{tabular}

Table 4. Crown volume, stem number (number of trunks) and trunk circumference of Argan young and old selected populations.

\begin{tabular}{lcccc}
\hline Tree ages & $\begin{array}{c}\text { Average crown } \\
\text { volume }\left(\mathbf{m}^{\mathbf{3}}\right)\end{array}$ & $\begin{array}{c}\text { Average stem } \\
\text { number }\end{array}$ & $\begin{array}{c}\text { Average total trunk } \\
\text { circumference }(\mathbf{m})\end{array}$ & $\begin{array}{c}\text { Trunk circumference } \\
\text { /Stem number }\end{array}$ \\
\hline Old trees $(>50$ years) & $141.48 \pm 84.6$ & $4.21 \pm 2.18$ & $2.85 \pm 1.22$ & $0.78 \pm 0.3$ \\
Young trees (7 years) & $8.45 \pm 5.38$ & $3.46 \pm 1.89$ & $0.78 \pm 1.36$ & $0.22 \pm 0.17$ \\
\hline
\end{tabular}

Table 5. Fruit yield of the 100 selected trees from each population (young and old) during 3 years (2014, 2015 and 2016).

\begin{tabular}{|c|c|c|c|c|c|c|c|c|c|c|c|c|}
\hline \multirow{2}{*}{ Trees } & \multicolumn{4}{|c|}{ Harvest $2014(\mathrm{~kg})$} & \multicolumn{4}{|c|}{ Harvest $2015(\mathrm{~kg})$} & \multicolumn{4}{|c|}{ Harvest 2016 (kg) } \\
\hline & Total & Average (per tree) & $\operatorname{Max}$ & Min & Total & Average (per tree) & Max & Min & Total & Average (per tree) & Max & Min \\
\hline Old trees (100) & 6220.50 & $62.2 \pm 21.59$ & 118.00 & 22.00 & 2787.00 & $27.87 \pm 17.03$ & 100.00 & 0 & 4006.00 & $40.06 \pm 23.24$ & 112 & 2 \\
\hline Young trees (100) & 118.70 & $1.18 \pm 1.5$ & 7.50 & 0 & 87.80 & $0.88 \pm 0.89$ & 5.00 & 0 & 200.98 & $2.01 \pm 1.91$ & 13 & 0 \\
\hline
\end{tabular}

Table 6. Percentage of fruit form by category of trees (young, old).

\begin{tabular}{lcccccc}
\hline Ages of trees & OvAp (\%) & OV (\%) & FF (\%) & R (\%) & D (\%) & PR (\%) \\
\hline Young trees (7 years) & 11.1 & 29.3 & 11.1 & 18.2 & 5 & 25.3 \\
Old trees (>50 years) & 22.8 & 40 & 8.6 & 14.2 & 13.4 & 1 \\
\hline
\end{tabular}

OvAp: Oval-apiculate, OV: Oval, FF: Fusiform, R: Rounded, D: Drop, PR: protruding. 
Table 7. Effect of fruit form on some selection parameters (Anova test).

\begin{tabular}{|c|c|c|c|c|c|c|c|c|c|c|c|c|}
\hline \multirow{2}{*}{ Factor } & \multicolumn{2}{|c|}{$\begin{array}{c}\text { Fruit } \\
\text { production }\end{array}$} & \multicolumn{2}{|c|}{$\begin{array}{c}\text { Number of } \\
\text { seeds in } 100 \mathrm{~g}\end{array}$} & \multicolumn{2}{|c|}{$\begin{array}{l}\text { Almond } \\
\text { yield }\end{array}$} & \multicolumn{2}{|c|}{$\begin{array}{l}\text { Ease of } \\
\text { crushing }\end{array}$} & \multicolumn{2}{|c|}{ Oil yield } & \multicolumn{2}{|c|}{$\begin{array}{c}\text { Alternation } \\
\text { rate }\end{array}$} \\
\hline & $\mathbf{F}$ & $\mathbf{P}$ & $F$ & $\mathbf{P}$ & $\mathbf{F}$ & $\mathbf{P}$ & $F$ & $\mathbf{P}$ & $\mathbf{F}$ & $\mathbf{P}$ & $\mathbf{F}$ & $\mathbf{P}$ \\
\hline Fruit form & 1.005 & 0.4 & 0.5 & 0.73 & 2.15 & 0.09 & 1.8 & 0.12 & 3.12 & $0.02^{*}$ & 0.62 & 0.64 \\
\hline
\end{tabular}

F: Factorial, P: p-value, ${ }^{*} P \leq 0.05$.

Table 8. Newman and Keuls test on yield average per fruit form.

\begin{tabular}{lccccc}
\hline Oil production/tree & OvAp & OV & D & FF & R \\
\hline Oil production per kg & $2.51 \pm 0.7^{\mathrm{b}}$ & $3.57 \pm 0.7^{\mathrm{a}}$ & $2.54 \pm 1^{\mathrm{b}}$ & $2.34 \pm 0.89^{\mathrm{b}}$ & $2.87 \pm 0.6^{\mathrm{ab}}$ \\
\hline $\begin{array}{l}\text { OvAp: Oval-apiculate, OV: Oval, D: Drop, FF: Fusiform, R: Rounded. Values having the same letter are not significantly different } \\
(p<0.05) \text {. }\end{array}$
\end{tabular}

Table 9. Effect of age on Argan oil yield in fruits and almonds.

\begin{tabular}{lcc}
\hline Type of trees & Almond oil content (\%) & Fruit oil content (\%) \\
\hline Young & $47.67 \pm 10.01^{\mathrm{a}}$ & $3.67 \pm 1.2^{\mathrm{a}}$ \\
Old & $46.67 \pm 3.74^{\mathrm{a}}$ & $3.05 \pm 0.54^{\mathrm{b}}$ \\
\hline
\end{tabular}

Values having the same letter in the same column are not significantly different $(p<0.05)$.

Table 10. Effect of age on crushing facility and spine number.

\begin{tabular}{lcc}
\hline Tree age & Crushing facility & Number of spines in $\mathbf{1 0} \mathbf{~ c m}$ \\
\hline Old & $0.09 \pm 0.05^{\mathrm{b}}$ & $3.5 \pm 3.08^{\mathrm{b}}$ \\
Young & $0.12 \pm 0.01^{\mathrm{a}}$ & $5.57 \pm 3.2^{\mathrm{a}}$ \\
\hline Values having the same letter in the same column are not significantly different \\
$(p<0.05)$.
\end{tabular}

The Newman and Keuls test (Table 8) reveals that the oval form shows a significant superiority in terms of oil production compared to the other types of fruits. Oval fruits produced the highest oil yield $(3.57 \%)$. Minimum values were obtained in fusiform fruits $(2.34 \%)$. These results are contradictory with the results obtained by Gharby (2012) who compared oil yield in 4 fruit forms; maximum value was observed in Oval-apiculate fruits and oval forms had the lowest content.

\section{Effect of age on Argan oil yield}

The age of trees has no effect on the oil yield of almonds in the Argan tree. The average oil content was $47.67 \%$ and $46.67 \%$ in young and old trees respectively (Table 9). On the other hand, fruits from young trees presented a highly significant superiority of $20 \%$ compared to the old ones.

The work of Bani-Aameur et al. (2010) showed that the content of almonds in oil is very variable among the genotypes; it oscillates between 44.1 and $39.2 \%$. In the present study, we found that yield can reach an average of $47.67 \%$, with regard to the effect of age of trees on fruit yield in oils. We have shown that fruits from young trees have significant superiority compared to the yield of old tree fruits.

\section{Effect of age on crushing facility and spines}

The age of the Argan trees has an important effect on the ease of crushing and also on the presence of spines. The fruits of young trees seemed the easiest to crush. Seeds with higher $A / G$ ratio are the easiest to crush. Comparing the two types of trees, the number of spines present in young trees is greater by $60 \%$ compared to old trees (Table 10).

\section{Selection of trees}

Principal Component Analysis (PCA) is a multivariate technique used in several studies. In our case, the PCA 
Table 11. Eigenvalues, cumulative variance of the first two principal components (PC) and the factorial loads between the $\mathrm{PC}$ and the traits studied in old trees.

\begin{tabular}{lcc}
\hline Variables & PC 1 & PC 2 \\
\hline Eigenvalue & 2.198 & 1.113 \\
Total variance explained (\%) & 34.33 & 22.67 \\
Total yield (TY) & 0.23 & -0.24 \\
Volume of crown (VC) & 0.87 & 0.18 \\
Yield / Volume (Y/C) & -0.87 & -0.19 \\
Number of stems (NS) & 0.45 & -0.25 \\
Total trunk circumference (TC) & 0.72 & -0.17 \\
Almond yield (AY) & 0.03 & -0.88 \\
Oil yield (OY) & 0.21 & -0.84 \\
Tree height (TH) & 0.64 & 0.30 \\
\hline
\end{tabular}

Table 12. Eigenvalues, cumulative variance of the first two principal components (PC) and the factorial loads between the PC and the traits studied in young trees.

\begin{tabular}{lcc}
\hline Variables & PC 1 & PC 2 \\
\hline Eigenvalue & 2.141 & 1.007 \\
Total variance explained (\%) & 42.62 & 18.98 \\
Total yield (TY) & -0.68 & 0.21 \\
Volume of crown (VC) & -0.93 & 0.24 \\
Yield / Volume (Y/C) & 0.67 & -0.17 \\
Number of stems (NS) & 0.42 & 0.75 \\
Total trunk circumference (TC) & 0.37 & 0.79 \\
Almond yield (AY) & -0.32 & 0.08 \\
Height of the Tree (HT) & -0.88 & 0.11 \\
\hline
\end{tabular}

was used to achieve two objectives:

1. Illustrate the correlations between parameters of the studied selections, and

2. Group together individuals of significant agronomic interest

The correlation between the selection parameters in the two types of trees is presented in Tables 11 and 12.

In old trees, the variability of the first two main components (PC1, PC2) was 34.33 and $22.67 \%$ respectively of the total variability. The illustrations of the PC1 and PC2 axes are shown in the Figures 2 and 3.

By analyzing the matrix of correlations, we deduce the presence of a positive correlation between the crown volume and the height of the tree and also between the branch of the trunk and the circumference of the barter. Which important to deduce is the utility of the first selection step which minimizes the overall variability of the major selection parameters: total fruit yield, almond yield and oil yield. On the other hand, a negative correlation between the yield of Almond and the oil yield with respect to the axis PC2.
Consequently, the PCA analysis revealed that the volume yield and crown volume are the most discriminating characters between the genotypes on the PC1 axis. On the other hand, the oil and almond yield is the most representative on the PC2. For the young trees, the variability of the two main components is 42.62 and $18.98 \%$. According to PC1, a negative correlation between crown volume, total yield, almond yield and tree height is deduced. On PC2, branching and trunk circumference are positively correlated. The Correlation Matrix Outcome Analysis shows that total yield, canopy volume, and tree height are major indicators of tree selection.

Regarding Argan trees selection, the most valuable parameters are related to oil production. In this context, the selected trees are those characterised by high total yield, high almond and oil yield; these parameters being correlated with high stem number. In fact these desirable parameters are highly correlated as illustrated in Figure 2. Figures 2 and 3 represent the projection of variables and individuals according to the studied parameters for old trees. Thus, the selected old trees are the individuals 9, 24, 1, 28 and 17 (Figure 3 and Table 13). 


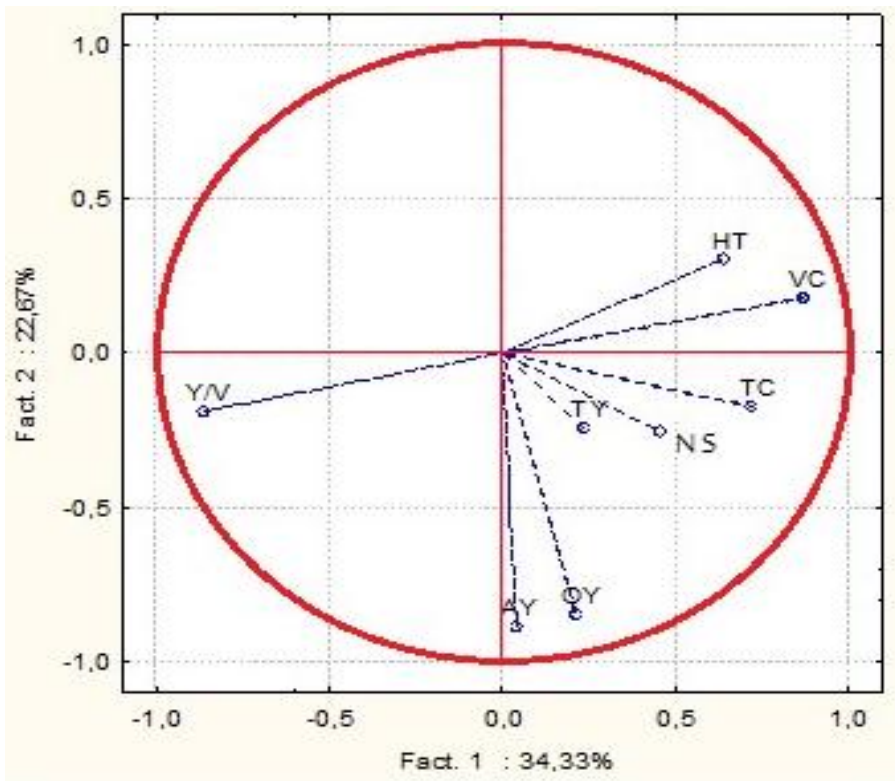

Figure 2. Projections of the variables studied according to factorial plans 1 and 2 for old trees.

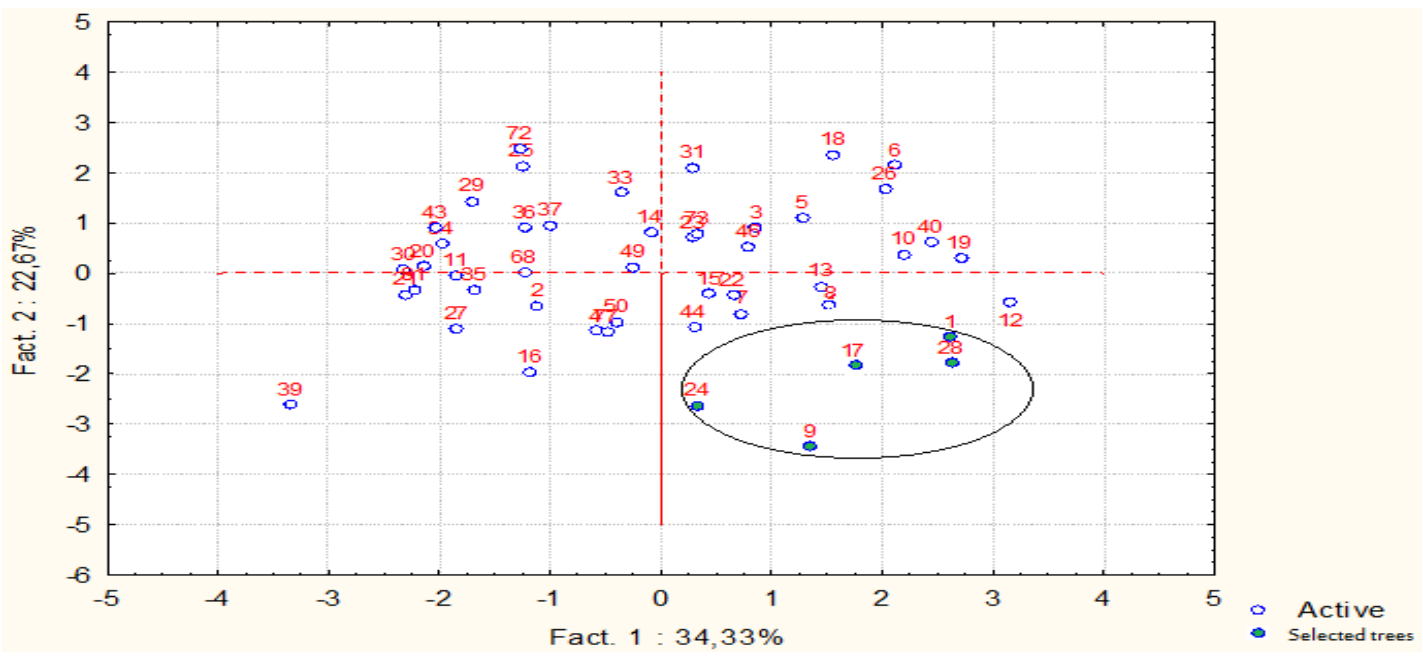

Figure 3. Projections of individuals studied according to factorial plans 1 and 2 for old trees.

With regard to young trees, the same protocols were followed. They enabled the identification of young individuals with interesting agronomic traits, the PCA projections of variables and individuals studied are shown in Figures 4 and 5. As reported for old trees, with the exception of stem number, the projection of parameters of young trees (Figure 4) shows that the major parameters of selection (total fruit yields, almond yield and crown volume) are highly correlated. Following these parameters, five young trees are selected for their performances, and the selected individuals are 1, 4, 7, 3 and 8 (Figure 5 and Table 14).

Analysis of PCA projection for the young Argan trees enabled the determination of the most efficient trees for qualitative and quantitative parameters (Figures 4 and 5). Table 14 shows the five selected individuals.

Previous work by Ferradous et al. (1997), Nouaim et al. (2002), Msanda et al. (2005), Nouaïm et al. (2007), Bellefontaine (2010) and Zunzunegui et al. (2010) and recent studies on agro-biodiversity and clonal propagation of the Argan tree (Ait Abd et al., 2013; Yatrib et al., 2015; Mouhaddab et al., 2017) have allowed to mark a significant number of trees with interesting agromorphological characteristics. This study has made it possible to choose a reduced number of trees from an overall number of 10,000 heterogeneous trees $(1,000$ old 
Table 13. Code and coordinates of selected old trees.

\begin{tabular}{llccc}
\hline \multirow{2}{*}{ Category of trees } & \multirow{2}{*}{ Tree code } & \multirow{2}{*}{ PCA code } & \multicolumn{2}{c}{ GPS coordinates } \\
\cline { 3 - 5 } & & & Latitude & Longitude \\
\hline \multirow{4}{*}{ Old } & OT16 & 9 & 30.334 & -9.424 \\
& OT120 & 24 & 30.333 & -9.433 \\
& OT176 & 1 & 30.335 & -9.436 \\
& OT182 & 28 & 30.334 & -9.437 \\
& OT218 & 17 & 30.334 & -9.426 \\
\hline
\end{tabular}

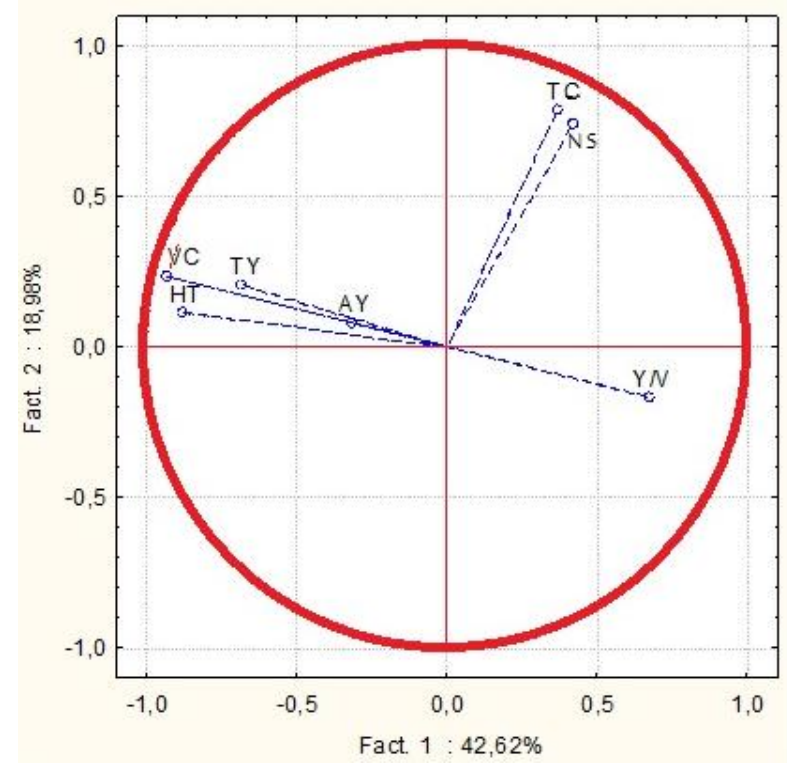

Figure 4. Projections of the variables studied according to factorial plans 1 and 2 for young trees.

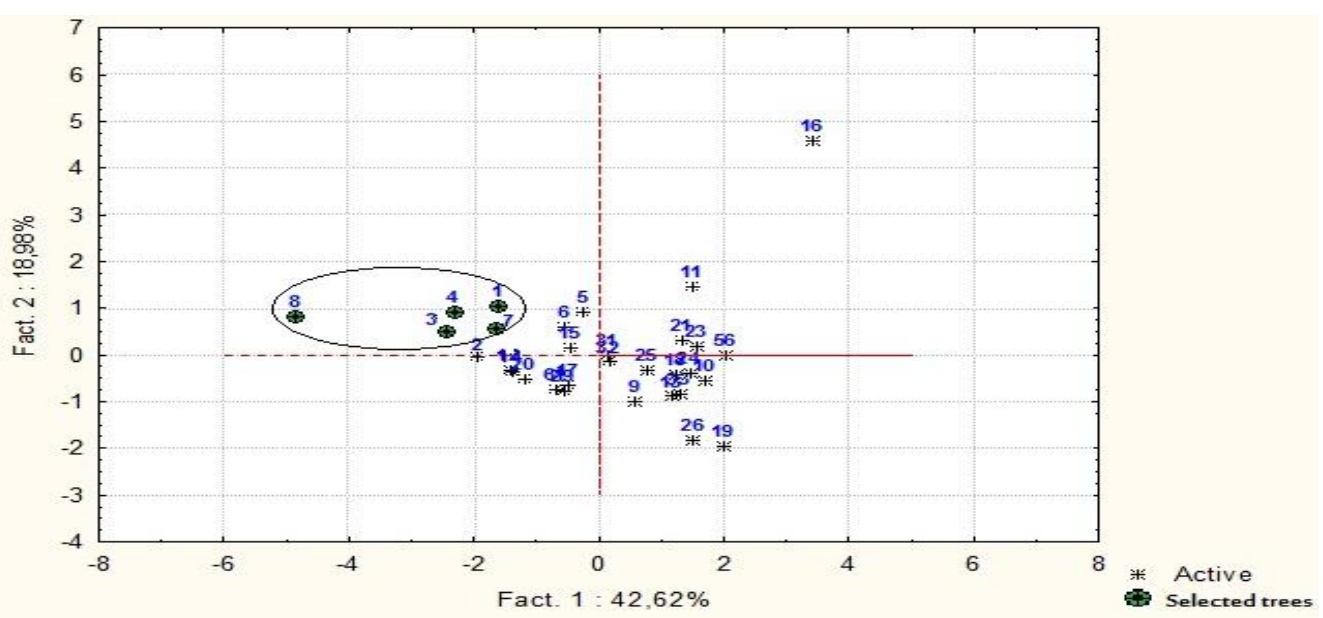

Figure 5. Projections of individuals studied according to factorial plans 1 and 2 for young trees.

trees and 9,000 young ones). Results of this work show that even under the same environmental conditions the Argan tree can express an interesting heterogeneity. This is largely in accordance with the literature cited above. Moreover, PCA has made it possible to determine the heads of clones with interesting agronomic characteristics. 
Table 14. Code and coordinates of selected young trees.

\begin{tabular}{llccc}
\hline \multirow{2}{*}{ Category of trees } & \multirow{2}{*}{ Tree code } & \multirow{2}{*}{ PCA Code } & \multicolumn{2}{c}{ GPS coordinates } \\
\cline { 4 - 5 } & & 4 & Latitude & Longitude \\
\hline \multirow{3}{*}{ Young } & YT33 & 3 & 30.333 & -9.429 \\
& YT47 & 3 & 30.334 & -9.430 \\
& YT101 & 7 & 30.334 & -9.436 \\
& YT106 & 1 & 30.334 & -9.437 \\
\hline
\end{tabular}

Table 15. Seasonal effect on annual fruit production (Anova test).

\begin{tabular}{lccc}
\hline \multirow{2}{*}{ Parameters } & \multicolumn{4}{c}{ Annual fruit production of adult trees $(\mathbf{k g})$} \\
\cline { 2 - 4 } & $\mathbf{D f}$ & $\mathbf{F}$ & $\mathbf{P}$ \\
\hline Factor (year) & 2 & 70.138 & $\mathbf{0 . 0 0 0 0 ^ { \star \star \star }}$ \\
\hline
\end{tabular}

Df: Degrees of freedom, F: Factorial, P: p-value, ${ }^{* \star *} P \leq 0.001$.

Table16. Correlation coefficients between climate data and fruit production.

\begin{tabular}{lcc}
\hline Climatic data & Fruit yield $(\mathbf{k g} /$ tree) & Fruit yield $\left(\mathbf{k g} / \mathbf{m}^{\mathbf{3}}\right)$ \\
\hline Strong winds (days) & -0.98 & -0.98 \\
Rainfall (mm) & 0.77 & 0.78 \\
Chergui winds (days) & -0.96 & -0.95 \\
\hline
\end{tabular}

\section{Relationship between fruit production and climatic factors}

Climatic conditions have generally significant effect on crop production. In the Argan trees studied, the climate induced a very highly significant difference in annual production (Table 15).

Such results have been found by other studies on other trees (Dokoozlian et al., 1995; Parciak, 2002). Zunzunegui (2010) have also mentioned that fruit yield is affected by environmental conditions. Bad climatic conditions (drought) reduce significantly fruit production in the Argan tree. In addition, our results (Table 15) showed that rainfall has a positive effect on fruit yield; the correlation test shows a correlation rate of $78 \%$. Castro (1999) showed that the occurrence of rainfall before maturation is associated with an increase in seed quality of Scots pine (Pinus sylvestris). Poor soil and lack of rain reduce fruit production and seed size (Schimpf, 1977; Medrano et al., 2003).

Besides, our results show that Chergui winds during the flowering period affect flowers and consequently reduce production. The analysis of the correlation tests between strong winds, the number of Chergui days during the flowering-setting period and the annual production shows a negative correlation of -98 and $-96 \%$, respectively.

Climatic conditions during flowering and fruit setting stages are very important in the production estimation.
The abundance or lack of rain, hot weather, strong winds and the occurrence of Chergui during this period significantly affect fruit yield and size. This is observed in other tropical species whose yields are related to climatic conditions during the flowering period (Frankie et al., 1974). In California's flora, Baker (1972) showed a positive correlation between favorable climatic conditions and seed weight. The production of fruit and flowers in tropical forest varies seasonally (Janzen, 1967; Baker, 1972; Frankie et al., 1974; Tutin et al., 1991; Tutin and Fernandez, 1993), the variation in the intensity of flowering in the Argan tree is conditioned by the geographical location (Bani-Aameur, 2001). Moreover pollination and pollen fertility affect fruit production to the extent that unfavorable climate has a significant effect on these factors (Belmouden and Bani-Aameur, 1995).

\section{CONCLUSION}

The results of this study illustrate the great genetic diversity existing among Argan trees as a forest species. The study of the quantitative and qualitative characteristics of Admin's Argan population reveals the presence of a great diversity between the studied individuals. This work allowed us to select the performing trees with high fruit and oil's production. Moreover, findings from this study would be useful in the choice of clone heads capable of being integrated into a clonal 
Intensification (propagation and establishment of plantations) program.

The identification of clone heads that are of economic interest is a first step to encourage Argan tree planting (plantation establishment) for production purposes. These clones may be recommended for local nursery growers to produce plant materials (seedlings). However, it is important to work on efficient methods for their vegetative propagation in order to conserve genetic characteristics. Currently, authors have reviewed several studies on the optimization of vegetative multiplication of the Argan tree (Ferradous et al., 2010, Kaaya, 1998; Harrouni, 1999; Nouaïm et al., 2007, Bellefontaine et al., 2010, Metougui et al., 2017). Their findings can be extrapolated to the selected Argan specimens of this work in order to improve rhizogenesis and seedling quality. The propagated seedlings can therefore be used in modern orchards as oil-bearing fruit trees.

\section{REFERENCES}

Aït Aabd N (2013). Apport des marqueurs phénotypiques et moléculaires pour l'analyse de la variabilité génétique de l'arganier Présélection pour le rendement en huile, Université lbn Zohr. p. 16

Aït Aabd N, El Ayadidi F, Msanda F, El Mousadik A (2010). Genetic variability of argan tree and preselection of the candidate plus trees. Notulae Botanicae Horti Agrobotanici Cluj-Napoca 38:293.

Azenfar A, Achour A, El Mousadik A, Fallah M (2007). Reconstitution de l'Arganeraie: Essais et Techniques de Régénération Artificielle chez Argania Spinosa L. Skeels, Annales de la recherche forestière au Maroc, Centre national de la recherche forestière, Rabat. pp. 5968.

Baker HG (1972). Seed weight in relation to environmental conditions in California. Ecology 53:997-1010.

Bani-Aameur F (2001). Floraison et production de fruits de l'arganier. Des modèles biologiques de l'amélioration des plantes. IRD:174-179.

Bani-Aameur F, Louali L, Dupuis P (2010). Maturation et chute des fruits de l'arganier. Revue Marocaine des Sciences Agronomiques et Vétérinaires 18:151-158

Bellefontaine R (2010). De la domestication à l'amélioration variétale de l'arganier (Argania spinosa L. Skeels) Science et changements planétaires/Sécheresse 21:42-53.

Bellefontaine R, Ferradous A, Alifriqui M, Montenuis O (2010). Multiplication végétative de l'arganier (Argania spinosa) au Maroc: le projet John Goelet. Bois et forêts des tropiques 304:47-59.

Belmouden S, Bani-Aameur F (1995). Contribution à l'étude de l'anthèse et de la viabilité du grain de pollen, Actes du Colloque International de la Foret Face à la désertification: Cas des Arganeraies. Faculté des Sciences d'Agadir. pp. 57-62.

Castro J (1999). Seed mass versus seedling performance in Scots pine: a maternally dependent trait. The New Phytologist. 144:153161.

Defaa C, Achour A, Hossayni A, Bellefontaine R, El Mousadik A, Msanda F (2013). Analyse de l'itinéraire technique d'un périmètre réussi de régénération d'arganier. ANDZOA, Actes du Premier Congrès International de l'Arganier pp. 83-92.

Dokoozlian N, Kliewer W (1995). The light environment within grapevine canopies. I. Description and seasonal changes during fruit development. American Journal of Enology and Viticulture 46:209218.

El Mousadik A (1997). Organisation de la diversité génétique de l'arganier Argania spinosa (L.) Skeels. Apport des marqueurs nucléaires et cytoplasmiques, Thèse de doctorat d'Etat, Université Ibn Zohr, Faculté des Sciences, Agadir.

El Mrabet S, Ouahmane L, El Mousadik A, Msanda F, Abbas Y (2014). The effectiveness of arbuscular mycorrhizal inoculation and bio-compost addition for enhancing reforestation with Argania spinosa in Morocco. Open J. For. 4(1):14-23.

Fallah M (2004). Amélioration de la croissance initiale de plants d'arganier. Influence de la protection individuelle à effet de serre et interaction avec le génotype. Thèse de doctorat d'Etat, Université Ibn Zohr, Faculté des Sciences, Agadir.

Ferradous A (1995). Diversités génétiques de quelques caractères morphologiques du fruit et de la graine d'arganier (Argania spinosa (L.) Skeels). DES, université Ibn Zohr, Agadir.

Ferradous A, Bani AF, Dupuis P (1997). Genetic diversity of Argania fruit and grain, Ressources Phytogenetiques et Developpement Durable, Rabat (Maroc), 1997, Actes Editions.

Ferradous A, Bani-Aameur F, Dupuis P (2010). Climat stationnel, phénologie et fructification de l'arganier (Argania spinosa L. Skeels). Revue Marocaine des Sciences Agronomiques et Vétérinaires 17:5160.

Frankie GW, Baker HG, Opler PA (1974). Comparative phenological studies of trees in tropical wet and dry forests in the lowlands of Costa Rica. J. Ecol. 881-919.

Gharby S (2012). Contribution à la valorisation de l'huile d'argan : Influence de l'origine du fruit (terroir, forme) et de la méthode d'extraction sur la composition chimique, les caractéristiques organoleptiques et la stabilité de l'huile d'argan. Thèse de doctorat d'Etat en Chimie organique. Université Mohammed V-Agdal, Faculté des Sciences, Rabat.

Harrouni M, El Kherrak H, Mokhtari M, El Yazidi A, Abdellah K (1999). Multiplication de l'Arganier (Argania spinosa (L.) Skeels) par bouturage. Proceedings of the International Conference on Biodiversity and Natural Resources Preservation. Al Akhawayn University, Ifrane, Morocco. May 13-15.

Janzen DH (1967). Why mountain passes are higher in the tropics. The American Naturalist 101:233-249.

Kaaya M (1998). Contribution à la domestication de l'arganier sélection et multiplication, Thèse, Université Ibn Zohr, Agadir, Maroc.

Medrano H, Escalona JM, Cifre J, Bota J, Flexas J (2003). A ten-year study on the physiology of two Spanish grapevine cultivars under field conditions: effects of water availability from leaf photosynthesis to grape yield and quality. Funct. Plant Biol. 30:607-619.

Metougui ML, Mokhtari M, Machati I, Azeroual I, Benlhabib 0 (2017). Multiplication végétative de l'arganier (Argania spinosa (L.) Skeels) par bouturage et par greffage. Revue Marocaine des Sciences Agronomiques et Vétérinaires, 5(4):428-436

Morton JF, Voss GL (1987). The argan tree (Argania spinosa L. Skeels), a desert source of edible oil. Econ. Bot. 41:221-233.

Mouhaddab J, Msanda F, Filali-Maltouf A, Belkadi B, Ferradouss A, EI Modafar C, Koraichi SI, El Mousadik A (2017). Using microsatellite markers to map genetic diversity and population structure of an endangered Moroccan endemic tree (Argania spinosa L. Skeels) and development of a core collection. Plant Gene. 10:5159

Msanda F (1993). Ecologie et cartographie des groupements végétaux d'Anzi (Anti-Atlas occidental, Maroc) et contribution à l'étude de la diversité génétique de l'arganier (Argania spinosa (L.) Skeels), Thèse de doctorat. Université de Grenoble I France.

Msanda F, El Aboudi A, Peltier JP (2005). Biodiversité et biogéographie de l'arganeraie marocaine. Cahiers Agric. 14:357-364.

Nouaïm R, Echairi A, Kaaya M, Chaussod R (2007). Contribution à la domestication de l'arganier pour la production d'huile. Agricultures 16:199-204.

Nouaïm R, Mangin G, Breuil M, Chaussod R (2002). The Argan tree (Argania spinosa) in Morocco: Propagation by seeds, cuttings and invitro techniques. Agrofor. Syst. 54:71-81.

Page AL, Miller RH, Keeny OR (1982). Methods of soil analysis. Madison: American Society of Agronomy.

Parciak W (2002). Environmental variation in seed number, size, and dispersal of a fleshy-fruited plant. Ecology 83:780-793.

Schimpf DJ (1977). Seed weight of Amaranthus retroflexus in relation to moisture and length of growing season. Ecology 58:450-453.

Tutin CE, Fernandez M (1993). Relationships between minimum temperature and fruit production in some tropical forest trees in Gabon. J. Trop. Ecol. 241-248. 
Tutin CE, Williamson EA, Rogers ME, Fernandez M (1991). A case study of a plant-animal relationship: Cola lizae and lowland gorillas in the Lopé Reserve, Gabon. J. Trop. Ecol. 7:181-199.

Yatrib C, Belkadi B, Pakhrou O, Alami M, Medraoui L, El A, Mousadik AF, Msanda F, El Modafar C, Souda-Kouraichi SI (2015). Assessment of genetic diversity of Argania spinosa L. growing in arid and semi-arid areas of Morocco as revealed by InterSimple Sequence Repeats. J. Agric. Sci. Technol. B 5:336-346.
Zunzunegui M, Aïn-Lhout F, Jáuregui J, Barradas MD, Boutaleb S, Álvarez-Cansino L, Esquivias M (2010). Fruit production under different environmental and management conditions of Argan, Argania spinosa (L.). J. Environ. 74:1138-1145.

http://www.sciencewebpublishing.net/jacr 